The following pages constitute the final, accepted and revised manuscript of the article:

Lindh, Christian $\mathrm{H}$ and Kristiansson, Monica $\mathrm{H}$ and Berg-Andersson, Ulrika A and Cohen, Arieh S

"Characterization of adducts formed between human serum albumin and the butadiene metabolite epoxybutanediol.”

Rapid Commun Mass Spectrom. 2005;19(18):2488-96.

Publisher: Wiley

Use of alternative location to go to the published version of the article requires journal subscription.

Alternative location: http://dx.doi.org/10.1002/rcm.2086 


\section{Characterization of adducts formed between human serum albumin and the butadiene metabolite epoxybutanediol.}

Christian H. Lindh ${ }^{1}$, Monica H. Kristiansson ${ }^{2}$, Ulrika A. Berg-Andersson ${ }^{3}$, and Arieh S. Cohen $^{1}$

${ }^{1}$ Department of Occupational and Environmental Medicine, Institute of Laboratory Medicine, Lund University Hospital, SE-221 85 Lund, Sweden

${ }^{2}$ Biological Engineering Division, Massachusetts Institute of Technology, 77 Massachusetts Avenue, Cambridge, MA 02139-4307, USA

${ }^{3}$ Ferring Pharmaceuticals A/S, Kay Fiskers Plads 11, 2300 Copenhagen, Denmark

* Correspondence to:

Christian Lindh, Department of Occupational and Environmental Medicine, Institute of Laboratory Medicine,

University Hospital, SE-221 85 Lund, Sweden

Phone: + 4646173819

Fax: +46 46143702

E-Mail: christian.lindh@ymed.lu.se

Running title - Adducts between human serum albumin and epoxybutanediol 


\begin{abstract}
1,3-butadiene (BD) has been classified as a potential human carcinogen. It occurs in the environment as well as in industrial settings. In humans, BD is readily metabolized to reactive epoxides (e.g. 1,2-epoxy-3,4-butanediol). In this study, conjugates between human serum albumin (HSA) and EBD were synthesized (molar ratios of 1:600, 1:1 and 1:0.1; HSA:EBD) under physiological conditions. The 1:600 conjugate and a blank HSA were digested with trypsin to obtain specific peptides, which were fractionated by preparative liquid chromatography (LC). The fractions were analyzed using nanoelectrospray quadrupole timeof-flight mass spectrometry (nanoES QqTOFMS). Adducted HSA tryptic peptides were identified and the adducted amino acid residues were pinpointed by tandem mass spectrometry (MS/MS) based sequence analysis. A total of 26, 2,3,4-trihydroxybutyl (THB) adducts were identified on 23 tryptic peptides in the HSA-EBD conjugate. The adducted amino acids were the $\mathrm{N}$-terminal aspartic acid residue, 6 glutamic acid residues, 5 histidine residues and 14 lysine residues. Results from the nanoES QqTOFMS experiments were used to set up a more sensitive liquid chromatographic- mass spectrometric (LC/MS) analysis using selected reaction monitoring (SRM). Eight of the adducted peptides could be detected in tryptic digests of the 1:0.1 HSA:EBD conjugate.
\end{abstract}




\section{Introduction}

1,3-Butadiene (BD) has been classified as a potential human carcinogen by the International Agency for Research on Cancer ${ }^{1}$ and as known human carcinogen by the U.S. Environmental Protection Agency ${ }^{2}$. Humans are subjected to BD exposure from environmental as well as occupational sources. BD can be found as a general air pollutant associated with burning of fossil fuel and biomass. Common sources include combustion emissions from motor vehicles and cigarette smoke. It is also used in vast amounts in the manufacturing of various synthetic rubbers and resins.

BD is oxidized by cytochrome P450 enzymes, forming the mutagenic epoxide metabolites 3,4-epoxy-1-butene (EB), 1,2,3,4-diepoxybutane (DEB) and 1,2-epoxy-3,4-butanediol (EBD). ${ }^{3,4}$. The epoxides can form adducts with macromolecules such as DNA and proteins. Protein adduct formation is considered to be a valuable surrogate for DNA adducts for biological monitoring of exposure. Several studies have been performed to characterize adducts formed between hemoglobin $(\mathrm{Hb})$ and the metabolites EB and DEB. Human $\mathrm{Hb}^{5-7}$ as well as mouse $\mathrm{Hb}^{8,9}$ has been studied. However, no studies have been performed for the structural characterization of adducts between any of the butadiene metabolites and HSA. This protein is the most prevalent protein of the blood plasma with an approximate half-life of 21 days. It has a variety of functions including the binding and transport of numerous endogenous substrates and xenobiotics.

The purpose of the present study was to determine the binding sites of the THB adducts with HSA formed by in vitro alkylation with high molar ratios of EBD. These results were then 
used to develop a more sensitive SRM based LC/MS method that was used to determine which adducted peptides that yielded the highest responses when lower molar ratios of EBD were used.

\section{MATERIALS AND METHODS}

Caution: EBD is hazardous and a potential carcinogen and must be handled with proper safety measures. Destruction of the epoxide was performed using $1 \mathrm{M} \mathrm{HCl}$.

\section{Chemicals and Materials}

EBD was synthesized by epoxidation of 3-butenediol, the product consisted of two stereoisomers and the purity was $98 \%$ determined by NMR (Synthelec AB, Lund, Sweden). Cesium Iodine (CsI) was purchased from Acros Organics (Geel, Belgium) and sex pheromone inhibitor iPD1 was obtained from Bachem (Bubendorf, Switzerland). Ammonium hydrogencarbonate $\left(\mathrm{NH}_{4} \mathrm{HCO}_{3}\right)$ came from BDH Laboratory Supplies (Poole, England). Dithiothreitol (DTT) and iodoacetamide were obtained from ICN Biomedicals Inc. (Ohio, USA). Acetonitrile and methanol came from Lab-Scan (Dublin, Ireland). Sodium chloride ( $\mathrm{NaCl})$, potassium chloride $(\mathrm{KCl})$, disodium hydrogen phosphate dihydrate $\left(\mathrm{Na}_{2} \mathrm{HPO}_{4} \cdot 2 \mathrm{H}_{2} \mathrm{O}\right)$, potassium dihydrogen phosphate $\left(\mathrm{KH}_{2} \mathrm{PO}_{4}\right)$, acetic acid and formic acid were obtained from Merck (Darmstadt, Germany). Trypsin (sequence grade) was obtained from Roche Diagnostics GmbH (Mannheim, Germany). HSA (fraction V), and trifluoraceticacid (TFA) were purchased from Sigma Chemicals (St. Louis, MO, USA). ZipTip $\mathrm{C}_{18}$ pipette tips were purchased from Millipore (Bedford, MA, USA). The dialysis membranes, with a cutoff at 3 500 Da, were purchased from Spectrum (Gardena, CA, USA). Nanospray capillaries were purchased from Protana Engineering A/S (Odense, Denmark) and New Objective Inc. (Woburn, MA, USA). Phosphate-buffered saline (PBS; $\mathrm{Na}^{+} 150 \mathrm{~mm}, \mathrm{~K}^{+} 4 \mathrm{~mm}$ ) was prepared 
by dissolving $\mathrm{NaCl}(8.0 \mathrm{~g}), \mathrm{Na}_{2} \mathrm{HPO}_{4}(1.4 \mathrm{~g}), \mathrm{KCl}(0.2 \mathrm{~g})$ and $\mathrm{KH}_{2} \mathrm{PO}_{4}(0.2 \mathrm{~g})$ in $1 \mathrm{~L}$ of water and the $\mathrm{pH}$ was adjusted to 7.4 with $0.1 \mathrm{M} \mathrm{NaOH}$.

\section{Instrumentation}

For the characterization of the peptides a nanoelectrospray source (nanoES) on a hybrid quadropole-time-of-flight mass spectrometer (QqTOFMS; Q-STAR, Applied Biosystems, Foster City, CA) was used. The mass spectrometer was calibrated daily using CsI $(\mathrm{m} / \mathrm{z}$ 132.9054) and the pentapeptide sex pheromone inhibitor iPD1 ( $\mathrm{m} / \mathrm{z} 829.5398)$. The data was evaluated using Analyst QS software with BioAnalyst ${ }^{\mathrm{TM}}$ extensions, supplied by Applied Biosystems. For increased sensitivity the digests were analyzed in SRM mode using triple quadrupole mass spectrometry with ESI on a turbo ionspray source (API 3000, Applied Biosystems) coupled to a liquid chromatography system from Perkin Elmer (Norwalk, Connecticut, USA; LC/MS).

\section{In-silico tryptic digests of HSA}

The sequence of HSA used in this study corresponds to the sequence entry in Swiss-Prot: P02768 without the first $24 \mathrm{~N}$-terminal amino acids. The HSA sequence used has a monoisotopic molecular weight of 66429 Da and consists of 585 amino acids. The theoretical $\mathrm{m} / \mathrm{z}$ of the tryptic digest products of HSA and the MS/MS fragment ion series of tryptic peptides were obtained using tools in the Analyst QS software. Lists showing the theoretical $\mathrm{m} / \mathrm{z}$ for the tryptic peptides were made using the software. The lists included various charge states of peptides, tryptic miss cleavages and the number of adducts. These lists were used as an aid in the identification of adducted peptides. The 79 theoretical tryptic peptides of HSA were abbreviated in sequence from T1 to T79. The nomenclature used was proposed by Roepstorff and Fohlman ${ }^{10}$. 


\section{In-vitro synthesis of HSA-EBD conjugates}

Purified HSA (fraction V) was used in the synthesis of the conjugates. EBD and HSA were dissolved in PBS pH 7.4. Different volumes of the EBD-solution were added to $1 \mathrm{~mL}$ of HSA solution (4 mg) and molar ratios of 1:600, 1:1 and 1:0.1 (HSA:EBD) were achieved. The solutions were incubated at $37^{\circ} \mathrm{C}$ for 5 days. A blank HSA sample was also prepared in PBS buffer and incubated under the same conditions. To remove reactive EBD, the samples were dialyzed (cutoff 3500 Da) against PBS buffer for seven days with five changes of buffer before further use. The dialysis time was chosen according to Rosqvist et al. ${ }^{11}$.

\section{Reduction of conjugates}

HSA contains 17 disulphide bonds and to obtain a more efficient digest as well as to prevent regeneration of disulphide bridges after trypsination, the conjugates and the blank HSA were reduced and carboxyamidomethylated. Four mg of the HSA-EBD conjugates and blank the HSA in $0.2 \mathrm{ml} 50 \mathrm{mM} \mathrm{NH}_{4} \mathrm{HCO}_{3}$ was mixed with $0.4 \mathrm{ml}$ DTT $(12 \mathrm{mg} / \mathrm{ml})$ at $55^{\circ} \mathrm{C}$ for $1 \mathrm{~h}$. The proteins were then carboxyamidomethylated with $0.4 \mathrm{ml}$ iodoacetamid $(25 \mathrm{mg} / \mathrm{ml})$ in darkness, at room temperature for $30 \mathrm{~min}$. The solutions were dialyzed against $50 \mathrm{mM}$ $\mathrm{NH}_{4} \mathrm{HCO}_{3}$ overnight to remove excess reagent.

\section{Digestion of HSA-EBD and HSA with trypsin}

Enzymatic digestion using trypsin was performed both on the conjugates and on the blank HSA. Trypsin was dissolved in $0.1 \mathrm{M} \mathrm{NH}_{4} \mathrm{HCO}_{3}(\mathrm{pH}$ 8.8) and added at a ratio of 1:50. Incubation was performed at $37^{\circ} \mathrm{C}$ overnight followed by evaporation to dryness. The samples were stored at $-20^{\circ} \mathrm{C}$ until further use. 


\section{Separation of tryptic peptides prior to qualitative analysis using preparative LC}

In order to facilitate the evaluation of the large number of peptides formed after tryptic digestion of the conjugates and the blank HSA, $0.8 \mathrm{mg}$ of the tryptic digests were separated and fractionated by preparative LC (Hewlett-Packard 1050; Palo Alto, CA, USA) on a $\mathrm{C}_{18}$ column (4.6 mm i.d. x 250 mm, Vydac). The mobile phase consisted of A: water and B: acetonitrile both containing $0.05 \%$ TFA. Separation was performed with gradient elution, 5 $\%$ to $60 \%$ of B between 1 and $51 \mathrm{~min}$. The flow rate was $1.0 \mathrm{~mL} \mathrm{~min}^{-1}$ and $1 \mathrm{~min}$ fractions were collected. The fractions were evaporated to dryness and stored at $-20^{\circ} \mathrm{C}$ until analysis on QqTOFMS.

\section{NanoES QqTOFMS analysis of tryptic digests}

The tryptic digests of EBD-conjugated HSA and blank HSA that had been fractionated by preparative LC were analyzed for adducts using nanoES QqTOFMS in the scanning MS mode and the MS/MS mode. The peptides in each fraction were dissolved in $30 \mu \mathrm{L}$ of water. Prior to analysis, $10 \mu \mathrm{L}$ of the fractions were acidified with $3 \mu \mathrm{L}$ TFA (2.5\% in water). The samples were purified and concentrated using $\mathrm{ZipTipC}_{18}$ pipette tips. The samples were eluted with $2 \mu \mathrm{L}$ 75\% methanol/10\% formic acid/ 15\% water directly into the nanospray needle. Adducted peptides were identified by comparison with the corresponding fraction for blank HSA and by comparison with lists of theoretical tryptic peptides of HSA both with and without adducts. Tandem mass spectrometry sequencing was used to confirm the adducted peptides identity and to identify which amino acid residue was adducted.

\section{LC/MS}


The tryptic peptides were also analyzed with a more quantitative approach using LC/MS in SRM mode. The peptides were separated on a Genesis $\mathrm{C}_{18}$ column (2.1 mm i.d. $\times 50 \mathrm{~mm}$; Jones Chromatography, Lakewood, CO, USA) with a mobile phase consisting of A: water and B: methanol, both containing $0.5 \%$ acetic acid. Separation was performed using a linear gradient between 5\% and 100\% B in 15 min. The injection volume was $20 \mu \mathrm{L}$ and the flow rate was $0.2 \mathrm{~mL} \mathrm{~min}{ }^{-1}$. The temperature of the auxiliary gas was set to $420{ }^{\circ} \mathrm{C}$ and the ion spray voltage to $5000 \mathrm{~V}$. Pure nitrogen was used as nebulizer, auxiliary, curtain, and collision gas.

A tryptic digest of the conjugate HSA-EBD 1:600 was used to tune the mass spectrometer for THB-adducted HSA peptides and $m / z$ transitions were selected for each adducted peptide in accordance with mass spectrometric data obtained from QqTOFMS analyses. In the first step a Q1 scan was performed to select the doubly or triply charged ions for each identified adducted peptide. In a second step, a product ion scan was performed for each of the 23 tryptic peptides in order to select the fragments with the highest intensity in the y- or b- series ions. In the third step a SRM method was created and the collision energies, focusing and the declustering potentials were optimized by infusion of the HSA-EBD conjugate 1:600. The analyses were performed with SRM in the positive ion mode and with a dwell time of $20 \mathrm{~ms}$. Alternate injections of methanol were made to exclude the risk of carry over-effects. Blank HSA digests were also injected to ensure that the adducted peaks originated from EBDconjugation. Once the parameters were optimized, digests of blank HSA and HSA adducted with molar ratios of 1:1 and 1:0.1 (HSA:EBD) were analyzed with the LC/MS method. 


\section{RESULTS}

\section{NanoES QqTOFMS analysis of tryptic digests}

When digesting the conjugate and the blank HSA a large number of peptides are formed. A strong ion suppression effect could be noted if crude digest was subjected to nanoES QqTOFMS. In order to facilitate the evaluation of the peptides the digest mixtures were fractionated using preparative LC. Each fraction was then subjected to nanoES QqTOFMS analysis. TOF spectra were generated for each conjugate fraction and the data were compared with the corresponding fraction from a blank HSA digest. Peptides observed with an addition of $m / z$ 104, or a multiple of 104 , corresponding to one or several THB adducts, were subjected to MS/MS. To identify the site of modification on the peptides and to confirm the sequence of a suspected adducted peptide, product ion analyses were carried out. The fragment series ions were used to elucidate which amino acid in the peptide sequence that EBD had bound to. The b- and/or y- series ions and immonium ions were the most prominent ions observed. Typical MS/MS spectra of adducted peptides are shown in figures 1 and 2 . The * denotes the modification sites of the peptides. In the HSA-EBD conjugate (1:600), a total of 26 THB adducted tryptic peptides were found (Table 1). No multiple adducts were observed in this study.

The identification of the modification site of an adduct on the peptide T45-46 (Figure 1) will be described in detail. The remaining 25 adducted peptides will only be descried briefly and only the crucial b, y, and immonium ions are listed. TOF spectra were obtained for the $26^{\text {th }}$ fraction of the conjugate digest as well as the corresponding fraction from the blank HSA. A prominent $[\mathrm{M}+2 \mathrm{H}]^{2+}$ ion $(\mathrm{m} / \mathrm{z}$ 786.50) was observed in the conjugate fraction and missing in the blank HSA. This ion could correspond to the miss-cleaved tryptic HSA peptide 
RHPDYSVVLLLR (T45-46) with an additional mass of 104. A product ion spectrum of the ion $\mathrm{m} / \mathrm{z} 786.50$ revealed partial y series ions from $\mathrm{y}_{1}$ ” to $\mathrm{y}_{10}$ ” however $\mathrm{y}_{11}$ ” could not be seen, instead $\mathrm{y}_{11}$ "* was observed. This indicates that histidine may be adducted. Moreover, the $\mathrm{b}_{1}$ ion was observed but not the $b_{2}$ ion, instead partial b- series ions with adducts, beginning with the $\mathrm{b}_{2} *$ ion $(\mathrm{m} / \mathrm{z} 398.24)$ was seen. In addition, a strong ion at $\mathrm{m} / \mathrm{z} 214.13$ could be observed in the spectrum, this corresponds to the THB-His immonium ion. Also, the theoretical fragment series ions for this adducted peptide provided by the software showed a close fit. Thus, the fragment series ions confirm the peptide RH*PDYSVVLLLR and also pinpoint His $^{338}$ as the most likely adduction site.

\section{$\mathrm{N}$-terminal adduct}

Peptide T01-02 (D*AHKSEVAHR; $[\mathrm{M}+3 \mathrm{H}]^{3+} ; \mathrm{m} / \mathrm{z}$ 418.56) showed an intense immonium ion corresponding to Asp-THB (m/z 192.09). Neither the $b_{1}$ nor the adducted $b_{1}{ }^{*}$ was detectable however the $\mathrm{b}_{2}{ }^{*}$ ion ( $\mathrm{m} / \mathrm{z}$ 291.14) was observed. The $\mathrm{y}_{7}$ ” was clearly visible. This suggests that the adduct was bound to the N-terminal Asp.

\section{Glutamic acid adducts}

Six adducted glutamic acid residues could be found in total. However, only three adducted peptides were observed. Each of these peptides had two reactive glutamic acids in the sequence. The analyzed peptides were a mixture of two adducted peptides with both sites adducted but not both simultaneously. All product ion spectra of peptides with adducted glutamic acid residues showed the immonium ion, Glu-THB at $m / z$ 206.11. The following identifications of peptides containing adducted Glutamic acids were made:

-Peptide T06 (LVNE*VTEFAK, LVNEVTE*FAK; $[\mathrm{M}+2 \mathrm{H}]^{2+} m / z$ 627.36) showed the adducted $\mathrm{b}_{4} *$ ion $\left(\mathrm{m} / \mathrm{z}\right.$ 560.29) along with $\mathrm{b}_{4}$ ion $(\mathrm{m} / \mathrm{z} 456.25)$ and $\mathrm{y}_{4} * *$ ion $(\mathrm{m} / \mathrm{z}$ 598.29) along 
with $y_{4}$ " ion ( $m / z$ 492.26). Thus both Glu ${ }^{45}$ and $\mathrm{Glu}^{48}$ appeared to be adducted, however not simultaneously.

-Peptide T34 (AE*FAEVSK, AEFAE*VSK; $[\mathrm{M}+2 \mathrm{H}]^{2+} \mathrm{m} / \mathrm{z} 492.75$ ) showed the adducted $\mathrm{b}_{2}{ }^{*}$ ion $\left(\mathrm{m} / \mathrm{z}\right.$ 305.13) but also the $\mathrm{b}_{2}$ ion $(\mathrm{m} / \mathrm{z} 201.09)$. The $\mathrm{y}_{4}$ ” ion $(\mathrm{m} / \mathrm{z} 462.25)$ appears as well as the adducted $\mathrm{y}_{4}{ }^{* *}$ ion ( $\mathrm{m} / \mathrm{z}$ 566.35). Moreover, the $\mathrm{y}_{7}{ }^{\prime}$ ion $\left(\mathrm{m} / \mathrm{z}\right.$ 913.46) and $\mathrm{y}_{7}{ }^{*} *$ ion $(\mathrm{m} / \mathrm{z}$ 913.46) could be observed in the same spectrum. This indicates that both $\mathrm{Glu}^{227}$ and $\mathrm{Glu}^{230}$ are adducted but not simultaneously.

-Peptide T48 (TYE*TTLEK ,TYETTLE*K; $\left.[\mathrm{M}+2 \mathrm{H}]^{2+} \mathrm{m} / \mathrm{z} 544.77\right)$ the $\mathrm{b}_{3} *$ ion $(\mathrm{m} / \mathrm{z} 498.21)$ as well as the $b_{3}$ ion $\left(m / z\right.$ 394.16) were observed. The adducted $b_{7} *$ ion ( $m / z$ 942.44), $\mathbf{y}_{2}{ }^{\prime *}$ ( $\mathrm{m} / \mathrm{z}$ 380.20) and $\mathrm{y}_{6}{ }^{* *}$ ion $(\mathrm{m} / \mathrm{z}$ 824.42) could be seen in the same spectra. This indicates that both $\mathrm{Glu}^{227}$ and Glu ${ }^{230}$ are adducted although not simultaneously.

\section{Histidine adducts}

Five adducted histidine residues were observed in the conjugate. Each product ion spectrum with an adducted histidine showed an immonium ion, His-THB ( $\mathrm{m} / \mathrm{z}$ 214.12). The following identifications of peptides containing adducted histidines were made:

-Peptide T02 (SEVAH*R; $\left.[\mathrm{M}+2 \mathrm{H}]^{2+} \mathrm{m} / \mathrm{z} 401.75\right)$ showed the $\mathrm{y}_{2}{ }^{\text {”* }}$ ion $(\mathrm{m} / \mathrm{z} 410.25)$, and the $\mathrm{b}_{5}{ }^{* *}$ ion $\left(\mathrm{m} / \mathrm{z}\right.$ 628.36). This confirmed the adduct at His ${ }^{9}$.

-Peptide T08 (SLH*TLFGDK; M+3H] $]^{3+} \mathrm{m} / \mathrm{z}$ 374.57) showed the $\mathrm{b}_{3}{ }^{*}$ ion $(\mathrm{m} / \mathrm{z}$ 442.25)

indicating $\mathrm{His}^{67}$ as the site of adduction.

-Peptide T12 (NECFLQH*K; $[\mathrm{M}+2 \mathrm{H}]^{2+} \mathrm{m} / \mathrm{z}$ 590.31) yielded strong y series ions including the adducted $\mathrm{y}_{2}{ }^{*} *$ ion ( $\mathrm{m} / \mathrm{z}$ 388.23), suggesting His ${ }^{105}$ as the adduct site.

-Peptide T18 (H*PYFYAPELLFFAK; $[\mathrm{M}+3 \mathrm{H}]^{3+} \mathrm{m} / \mathrm{z}$ 616.3) yielded the adducted $\mathrm{b}_{1}$ * ion $(\mathrm{m} / \mathrm{z}$ 242.15), suggesting an adducted His ${ }^{146}$. 
-Peptide T45-46, (RH*PDYSVVLLLR; $[\mathrm{M}+2 \mathrm{H}]^{2+} \mathrm{m} / \mathrm{z}$ 786.50) has been described in detail above (Figure 1).

\section{Lysine adducts}

A total of 14 lysine adducts could be identified in the conjugate. No Lys-THB immonium ions could be identified in any of the spectra. The trypsin was not able to cleave the protein at lysine residues with a THB adduct. Thus, all trypic peptides containing adducted lysine residues contained at least one missed cleavage. The following identifications of peptides containing adducted lysines were made:

-Peptide T03-T04 (FK*DLGEENFK; $\left.[\mathrm{M}+\mathrm{H}]^{3+} \mathrm{m} / \mathrm{z} 444.24\right)$ showed an adducted $\mathrm{b}_{2}{ }^{*}(\mathrm{~m} / \mathrm{z}$ 380.22). Lys ${ }^{12}$ was suggested to be the site of adduction.

- Peptide T15-T16 (K*YLYEIAR; $[\mathrm{M}+3 \mathrm{H}]^{3+} \mathrm{m} / \mathrm{z}$ 387.23) showed an adducted b-ion series. The $b_{1}{ }^{*}$ ion $\left(m / z\right.$ 233.15) was clearly observed. The likely adduction site was Lys ${ }^{137}$. -Peptide T27-T28 ( LK*CASLQK; $[\mathrm{M}+3 \mathrm{H}]^{3+} \mathrm{m} / \mathrm{z}$ 351.53) showed an adducted $\mathrm{b}_{2}{ }^{*}$ ion $(\mathrm{m} / \mathrm{z}$ 346.23) making Lys ${ }^{199}$ the probable adduction site.

-Peptide T30-T31 (AFK*AWAVAR; $[\mathrm{M}+2 \mathrm{H}]^{2+}, \mathrm{m} / \mathrm{z}$ 562.35) yielded the adducted $\mathrm{b}_{3} *$ ion ( $m / z$ 451.26) and $\mathrm{y}_{7}{ }^{* *}$ ion $\left(\mathrm{m} / \mathrm{z}\right.$ 905.61) ions. Thus, Lys ${ }^{212}$ was confirmed as the adduct site. -Peptide T33-34 (FPK*AEFAEVSK; $[\mathrm{M}+2 \mathrm{H}]^{2+}, \mathrm{m} / \mathrm{z}$ 678.86) yielded the $\mathrm{b}_{3}{ }^{*}$ ion $(\mathrm{m} / \mathrm{z} 477.27)$ and y9 $_{9} *$ ion $\left(m / z\right.$ 1112.58) ions making Lys ${ }^{225}$ the adduction site.

-Peptide T34-35 (AEFAEVSK*LVTDDLTK; $[\mathrm{M}+3 \mathrm{H}]^{3+}, \mathrm{m} / \mathrm{z}$ 585.65) provided the $\mathrm{b}_{8} *(\mathrm{~m} / \mathrm{z}$ 1021.65) and $\mathrm{y}_{8}{ }^{* *}\left(\mathrm{~m} / \mathrm{z}\right.$ 966.49) ions making Lys ${ }^{233}$ the adduction site.

-Peptide T47-T48 (LAK*TYETTLEK; $[\mathrm{M}+3 \mathrm{H}]^{3+} \mathrm{m} / \mathrm{z}$ 467.60) showed the $\mathrm{b}_{3}$ * ion $(\mathrm{m} / \mathrm{z}$ 417.26) which made $\mathrm{Lys}^{351}$ the likely adduction site.

-Peptide T50-51 (VFDEFK*PLVEEPQNLIK; $[\mathrm{M}+3 \mathrm{H}]^{3+} \mathrm{m} / \mathrm{z}$ 717.05) showed the $\mathrm{b}_{6}{ }^{*}$ ion $(\mathrm{m} / \mathrm{z}$ 870.47) and $\mathrm{y}_{12}{ }^{\prime *}$ ion $\left(\mathrm{m} / \mathrm{z}\right.$ 1511.95). Thus, $\mathrm{Lys}^{378}$ was confirmed as the adduct site. 
-Peptide T54-55 (K*VPQVSTPTLVEVSR; $[\mathrm{M}+3 \mathrm{H}]^{3+}$ ion $\mathrm{m} / \mathrm{z}$ 582.06) yielded no $\mathrm{b}_{1}$ * ion, but an adducted $b$ ion series beginning from $b_{2} *$ ion $(m / z$ 332.25) was observed. The $y$-ions series from $\mathrm{y}_{1}$ "-y9" were observed. The likely site of adduction was Lys ${ }^{414}$. -PeptideT56-57 (NLGK*VGSK; $[\mathrm{M}+2 \mathrm{H}]^{2+} \mathrm{m} / \mathrm{z}$ 453.81) showed only a few b series ions however the native $\mathrm{y}$-series ions $\mathrm{y}_{1}$ ” - $\mathrm{y}_{4}$ ” and the adducted $\mathrm{y}_{5}{ }^{\prime *}$ ion $(\mathrm{m} / \mathrm{z} 622.36)$ made Lys ${ }^{432}$ the likely site of adduction.

-Peptide T63-64 (VTK*CCTESLVNR; $[\mathrm{M}+3 \mathrm{H}]^{3+} \mathrm{m} / \mathrm{z}$ 524.29) gave a clear $\mathrm{b}_{3}{ }^{*}$ ion $(\mathrm{m} / \mathrm{z}$ 433.27) the adducted $\mathrm{y}_{9}$ ”* ion was not observed but the $\mathrm{y}_{1}$ ”- $\mathrm{y}_{8}$ ” series ions was clearly visible. Thus, Lys $^{475}$ was the likely adduction site.

-Peptide T69-T70 (K*QTALVELVK; $[\mathrm{M}+2 \mathrm{H}]^{2+}$ m/z 616.93) yielded very strong $\mathrm{b}^{*}$ - ion series. The series began with the $b_{1} *$ ion $\left(m / z\right.$ 233.16). Parts of the $y$ - series ions between $y_{1}$ ” - y9” were also observed. This suggested an adduct on Lys $^{525}$ (Figure 2).

-Peptide T72-T73 (ATK*EQLK ; $[\mathrm{M}+2 \mathrm{H}]^{2+} \mathrm{m} / \mathrm{z}$ 461.32) showed a clear $\mathrm{b}_{3} *$ ion $(\mathrm{m} / \mathrm{z}$ 405.27) and $\mathrm{y}_{6}{ }^{* *}$ ion $\left(\mathrm{m} / \mathrm{z}\right.$ 850.56) thus Lys ${ }^{541}$ was adducted.

-Peptide T78-T79 (K*LVAASQAALGL ; $[\mathrm{M}+2 \mathrm{H}]^{2+}$ m/z 623.44) only showed the $\mathrm{y}_{2}$ ” - $\mathrm{y}_{4}$ ” series ions. The $b_{1} *$ ion could not be observed but the b-series ions from $b_{2} *$ ion $(m / z 346.28$ $\mathrm{b}_{11} *\left(\mathrm{~m} / \mathrm{z}\right.$ 1114.74) indicates that Lys ${ }^{574}$ may be adducted.

\section{LC/MS analysis of tryptic digests}

Tryptic peptides from an HSA-EBD conjugate 1:600 were used to tune the LC/MS instrument. A Q1 scan was performed to compare the charge state of the peptides with the results from the QqTOFMS analysis. It was found that the highest signal was obtained for the peptides in the same charge state as obtained when using the QqTOFMS instrument (data not shown). In the second step, product ion scans were performed for each of the 23 tryptic peptides in order to select the fragments ions with the highest response. The collision energy 
was initially chosen for each peptide based on charge state, peptide length and experience from the QqTOFMS analysis. In the third step, a SRM method was created. The SRM method consisted of 59 transitions, each with a dwell time of 20 msec. This entails 1.47s for each scan cycle corresponding to about 10-12 data points for each peak. The collision energies, focusing and the declustering potentials were optimized by ramping the potentials for each parameter during a constant infusion of the HSA-EBD conjugate 1:600.

After the MS parameters were optimized, the peptides were analyzed in SRM mode. The peptides were separated using a $5 \mathrm{~cm} \mathrm{C}_{18}$ column using a 15 min gradient. The method was then applied on tryptic peptides from a digested blank HSA, HSA-EBD conjugate 1:600, 1:1 and 1:0.1. The detection limit was defined using the conjugate 1:0.1 and the blank HSA digests. The response of the peaks in the 1:0.1 conjugate had to at least three times the noise level observed at the same retention time in a blank HSA digest. Also, the response had to be higher than a signal/noise ratio of 3/1 within the chromatogram in the conjugate 1:0.1. All 26 THB adducts were observed when the 1:600 conjugate was analyzed. The peptides detected in the 1:0.1 conjugate are shown in Table 2 . In the 1:1 conjugate all the modified peptides found in the 1:0.1 conjugate were observed. In addition, the lysine adducts, Lys ${ }^{12}$, Lys $^{233}$, Lys ${ }^{351}$ and Lys ${ }^{375}$ could be detected. Typical chromatograms are shown in Figures 3 and 4. In total, 9 adducted amino acid moieties contained in 8 of the THB adducted tryptic peptides could be observed in the lowest conjugate HSA-EBD conjugate (1:0.1). These peptides were detected using a total of 13 SRM transitions. To ensure a successful tryptic digest, the non-adducted tryptic HSA peptide T08 (SLHTLFGDK) was monitored as a marker of digestion at the transitions $[\mathrm{M}+2 \mathrm{H}]^{2+} \rightarrow \mathrm{y}_{6}{ }^{\prime \prime}(\mathrm{m} / \mathrm{z}: 509.27 \rightarrow 680.4)$. 
Although no cysteine adducts were detected in the nanoES QqTOFMS analysis, possible cysteine adducts were monitored by SRM in the LC/MS analysis. To detect the presence of THB adducts bound to $\mathrm{Cys}^{34}$ the peptide T05, ALVLIAFAQYLQQC(*)PFEDHVK was analyzed both in the carboxyamidomethylated form and in the potentially adducted form. For the carboxyamidomethylated peptide a large part of the $y$ - series ions could be observed. The highest intensity was found when monitoring the $[\mathrm{M}+3 \mathrm{H}]^{3+}$ at $\mathrm{m} / \mathrm{z} 831.09$ as well as the fragment ions $y_{4}$ ion $\left(\mathrm{m} / \mathrm{z}\right.$ 498.3), the doubly charged $\mathrm{y}_{9}$ ” ion $(\mathrm{m} / \mathrm{z} 580.8)$ and $\mathrm{y}_{10}$ ” ion $(\mathrm{m} / \mathrm{z}$ 644.8). The carboxyamidomethylated peptide provided a clearly visible response in SRM mode. To detect the potentially adducted peptide the transitions of $[\mathrm{M}+3 \mathrm{H}]^{3+}$ at $\mathrm{m} / \mathrm{z} 846.4$ to the fragment ions $\mathrm{y}_{4}$ ion $\left(\mathrm{m} / \mathrm{z}\right.$ 498.3), the doubly charged $\mathrm{y}_{8}{ }^{*}$ ” ion $(\mathrm{m} / \mathrm{z} 539.7), \mathrm{y}_{9}{ }^{*}$ ” ion $(\mathrm{m} / \mathrm{z}$ 603.8) and $\mathrm{y}_{10}{ }^{* ”}$ ion $(\mathrm{m} / \mathrm{z}$ 667.8) were monitored. None of these provided a response in any of the three conjugates.

\section{DISCUSSION}

This study shows that EBD forms THB adducts with HSA in vitro. Adducted tryptic peptides and THB adduct positions were initially identified with nanoES-QqTOFMS. The information obtained in these experiments was then used to set up an LC/MS analysis where SRM was used to detect adducted peptides. NanoES QqTOFMS proved to be a powerful tool for identification of the modification sites. The small sample consumption when using nanospray allows MS and MS/MS experiments to be performed during periods of time of up to several hours. When identifying modification sites in peptides from MS/MS spectra, many data points are often necessary to produce detailed spectra that are easily interpretable. Furthermore, fragmentation parameters e.g. collision energy, often has to be varied between peptides to obtain a spectra of high quality that demonstrates clear fragment series ions. Thus, nanoES was more convenient in this study, compared to on-line LC analysis, for the identification of 
modification sites. The drawback is the time consumption. On the other hand LC/MS/MS with SRM provided higher sensitivity, which was necessary when the 1:1 and 1:0.1 conjugates were analysed.

The initial identification of adducted peptides was achieved by comparing full scan mass spectra of corresponding fractions of tryptic digest of EBD-HSA and blank HSA. At this stage 1:600 HSA:EBD conjugates were used. Mass spectrometric peaks that displayed a mass difference of 104 or a multiple of 104 between corresponding fractions were subjected to MS/MS in order to identify the peptide and the adducted amino acid moieties. A total of 26 THB adducts were identified on 23 tryptic peptides in the HSA-EBD conjugate (Table 1). Product ion spectra were used to identify the sites of modification on the peptides and to confirm the sequence of suspected adducted peptides. The fragment series ions were used to pinpoint the site of adduction. The b- and/or y- series ions and immonium ions were the most useful ions when determining the site of modification. The software also provided theoretical fragment series ions that were useful when confirming adducted peptides.

The adducted glutamic acid residues and adducted histidine residues provided immonium ions upon fragmentation, which facilitated the determination of the adduction sites. Lysine, on the other hand did not provide immonium ions. However, the trypsin was not able to cleave the protein at adducted lysine residues. Thus, all peptides with adducted lysine residues consisted of two adjacent tryptic peptide sequences. This was helpful in identifying lysine adducts modification sites. Similar miscleavages have also been observed in other studies ${ }^{9,12}$. The amino acids found to carry THB adducts at physiological $\mathrm{pH}$ were the N-terminal aspartic acid residue, glutamic acid residues, histidine residues, and lysine residues. 
At a molar ratio of 1:0.1 (HSA:EBD) THB adducts could be found on the amino acids, Glu ${ }^{353}$, $\mathrm{Glu}^{349}$, $\mathrm{His}^{9}, \mathrm{His}^{67}, \mathrm{His}^{146}$, $\mathrm{His}^{338}$, Lys ${ }^{199}$, Lys $^{414}$ and Lys ${ }^{525}$. Adduct binding of EBD (or any other of BD’s metabolites) to HSA has not previously been studied.

However, several of the identified amino acids have previously been identified as important adduct binding sites (His ${ }^{146 ; 13,14}$ His $^{338 ; 15}$, Lys $^{199 ; 12,16-22}$, Lys ${ }^{414 ;}$ 15 Lys $^{525 ; ~ 18,21}$ ) in HSA. In particular, lysine ${ }^{199}$ has been identified as a reactive amino acid moiety of HSA towards several classes of compounds. In our study the peptide containing Lys $^{525}$ provided an outstanding signal. In a study by Iberg et al. $\mathrm{Lys}^{525}$ was shown to be the main glycolysation site on $\mathrm{HSA}^{18}$.

Several studies have shown that the n-terminal valine of $\mathrm{Hb}$ reacts readily with EB, DEB and EBD. Adducts to the n-terminal valine of $\mathrm{Hb}$ has been used as a biomarker for exposure to $\mathrm{BD}^{23-28}$. In our study, the n-terminal Asp of HSA was found to carry an THB adduct at molar ratios of 1:600 (HSA:EBD). However, at molar ratios of 1:1 and 1:0.1 (HSA:EBD) THB adducts could not be observed even when using LC/MS in SRM mode. This may indicate that the n-terminal Asp in HSA is less reactive than the n-terminal Val of Hb. This has also been observed in other studies of reactive compounds with a quantitative approach and concerning both $\mathrm{Hb}$ and HSA ${ }^{21,29}$.

As mentioned above, $\mathrm{BD}$ is metabolized to three reactive epoxides. Adduct formation of the other two reactive metabolites, EB and DEB ${ }^{5-8}$ has been studied using similar approaches using Hb. It would be reasonable to expect these epoxides to react with similar amino acid moieties as EBD. Moll et al. ${ }^{8}$ studied adduct formation of EB to mouse Hb. Adducts were found bound to Val, His and Lys in this study whereas no cystein adducts were observed. In a 
study of adduct formation of DEB to human Hb by Basile et al. ${ }^{6}$ no Lys adducts were found however they did find Val, His, Glu and Cys adducts. Miraglia et al. ${ }^{5}$ identified Val, His and Cys adducts of DEB in human Hb. Also Badghisi et al. ${ }^{7}$ identified Val and Cys adducts of DEB in human Hb. In all studies the n-terminal valine was identified as a main site of adduction. Clearly, these studies are not in complete agreement, however one should keep in mind that the different epoxides and the different HBs may not react in exactly the same way. Differences in the findings may also depend on differences in the amino acid sequence in the proteins. Adjacent amino acids or the protein confirmation may affect the formation of adducts. Also differences in experimental conditions used during alkylation, e.g. pH could affect the adduct formation. In a study of interactions between peptides and DEB by Cech et al. ${ }^{30} \mathrm{DEB}$ was found to be mostly reactive to Arg, when the synthesis was performed in 0.1 $\mathrm{M} \mathrm{NaOH}$. Despite the differences between these studies, all the adducted amino acid moieties identified in this study (Glu, His and Lys) have previously been found to carry adducts. No Cys adducts were observed in this study although Cys residues in HSA and Hb have been shown to be reactive towards epoxides. The THB adducts to Cys are likely to be stable. However, the reduction of HSA followed by the carboxyamidomethylation could affect the stability of the THB adduct. If this step was omitted the trypsination was inefficient. (data not shown)

When characterizing the adducts formed between to HSA and EBD using nanoESQqTOFMS, high molar ratios between HSA and EBD was required in order to achieve interpretable spectra. In a previous study by Basile et al. ${ }^{6}$ there appears to be a higher response for peptides with THB adducts compared to our study. In that study the molar ratio was 1:10 (HSA:DEB) and the reaction time was shorter. Thus the modification rate in our study appears to be low. It is, however, difficult to judge if the sensitivity is due to a low 
modification rate of the epoxide to HSA or if the THB adducted peptides provide a low response in the mass spectral analysis. It is also possible that DEB is more reactive than EBD. The studied adducts can be considered to be stable both from a chemical and a mass spectrometric standpoint. The reaction was allowed to take place for a five-day period at 37 ${ }^{\circ} \mathrm{C}$ followed by 7 days of dialysis. Chemically unstable adducts and reactive epoxides would likely to have been removed during this treatment.

Although quantification of these peptides was beyond the scope of this investigation, it was surmised that these peptides were the most reactive towards EBD at physiological $\mathrm{pH}$. Ultimately, the LC/MS method would be an attractive analytical method for biological monitoring of exposure to BD. Unfortunately, the in vitro conjugates used in this study corresponds to unrealistically high exposure levels as compared to what can be found in vivo after BD exposure. Recently, Boysen et al. employed an immunoaffinity sample preparation column to selectively trap and enrich a cyclic n-terminal DEB adduct ${ }^{31}$. Using a similar immunoaffinty column for sample enrichment it would be feasible to use the LC/MS method for biological monitoring.

\section{CONCLUSIONS}

This study shows that THB adducts are formed with HSA after reaction with EBD in vitro. Conjugates between HSA and EBD were characterized using nanoES-QqTOFMS. For increased sensitivity a LC/MS method using SRM was applied. At a molar ratio of 1:0.1 (HSA:EBD) THB adducts could be found on the amino acids, Glu ${ }^{353}$, Glu ${ }^{349}$, $\mathrm{His}^{9}$, $\mathrm{His}^{67}$,

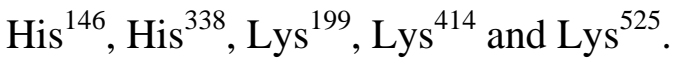




\section{ACKNOWLEDGMENTS}

This work was supported by the Swedish Council for Working Life and Social Research, the Swedish Research Council for Environment, Agricultural Sciences, and Spatial Planning, the Royal Physiographic Society in Lund and the Medical Faculty at Lund University. 
Table 1. Summary of THB modified peptides and the positions of the adducts found on nanoES QqTOFMS analysis of tryptic digests of conjugate HSA:EBD 1:600.

\begin{tabular}{|c|c|c|c|c|}
\hline $\begin{array}{c}\text { position of } \\
\text { adduct }\end{array}$ & $\begin{array}{l}\text { Charge } \\
\text { state }\end{array}$ & $\mathrm{m} / \mathrm{z}$ & Sequence & $\begin{array}{c}\text { Modified } \\
\text { peptide }\end{array}$ \\
\hline Asp1 & 3 & 418.56 & D*AHKSEVAHR & T01-02 \\
\hline $\mathrm{Glu}^{45}$ & 2 & 627.36 & LVNE*VTEFAK & T06 \\
\hline $\mathrm{Glu}^{48}$ & 2 & 627.36 & LVNEVTE*FAK & T06 \\
\hline $\mathrm{Glu}^{227}$ & 2 & 492.75 & AE*FAEVSK & T34 \\
\hline $\mathrm{Glu}^{230}$ & 2 & 492.75 & AEFAE*VSK & T34 \\
\hline $\mathrm{Glu}^{349}$ & 2 & 544.77 & TYE*TTLEK & $\mathrm{T} 48$ \\
\hline Glu $^{353}$ & 2 & 544.77 & TYETTLE*K & T48 \\
\hline His $^{9}$ & 2 & 401.75 & SEVAH*R & T02 \\
\hline His $^{67}$ & 3 & 374.57 & SLH*TLFGDK & T08 \\
\hline His $^{105}$ & 2 & 590.31 & $\mathrm{NEC}^{\mathrm{a}} \mathrm{FLQH}^{*} \mathrm{~K}$ & $\mathrm{~T} 12$ \\
\hline His $^{146}$ & 3 & 616.37 & H*PYFYAPELLFFAK & $\mathrm{T} 18$ \\
\hline His $^{338}$ & 2 & 786.50 & RH*PDYSVVLLLR & T45-46 \\
\hline Lys $^{12}$ & 3 & 444.24 & FK*DLGEENFK & T03-04 \\
\hline Lys $^{137}$ & 3 & 387.23 & K*YLYEIAR & T15-16 \\
\hline Lys $^{199}$ & 3 & 351.53 & $\mathrm{LK}^{*} \mathrm{C}^{\mathrm{a}} \mathrm{ASLQK}$ & $\mathrm{T} 27-28$ \\
\hline Lys $^{212}$ & 2 & 562.35 & AFK*AWAVAR & Т30-31 \\
\hline $\operatorname{Lys}^{225}$ & 2 & 678.86 & FPK*AEFAEVSK & Т33-34 \\
\hline $\operatorname{Lys}^{233}$ & 3 & 585.65 & AEFAEVSK*LVTDLTK & Т34-35 \\
\hline Lys $^{351}$ & 3 & 467.60 & LAK*TYETTLEK & T47-48 \\
\hline Lys $^{378}$ & 3 & 717.05 & VFDEFK*PLVEEPQNLIK & T50-51 \\
\hline $\operatorname{Lys}^{414}$ & 3 & 582.06 & K*VPQVSTPTLVEVSR & T54-55 \\
\hline $\operatorname{Lys}^{432}$ & 2 & 453.81 & NLGK*VGSK & T56-57 \\
\hline Lys $^{475}$ & 3 & 524.29 & VTK $* C^{\mathrm{a}} \mathrm{C}^{\mathrm{a}}$ TESLVNR & T63-64 \\
\hline Lys $^{525}$ & 2 & 616.93 & K*QTALVELVK & T69-70 \\
\hline Lys $^{541}$ & 2 & 461.32 & ATK*EQLK & T72-73 \\
\hline Lys $^{574}$ & 2 & 623.44 & K*LVAASQAALGL & T78-79 \\
\hline
\end{tabular}


Table 2. Summary of the SRM transitions of modified peptides and the positions of the adducts found in LC-MS/MS analysis of tryptic digests of conjugate HSA:EBD 1:0.1. The declustering potentials (Dp) and collision energies (Ce) for each transition are tabulated. The residues found to be adducted with THB adducts are denoted with a*.

Position of

Adduct

Transitions

$\mathrm{Glu}^{349}$

$544.9 \rightarrow 824.3$

Transitions

Sequence

Dp

$\mathrm{Ce}$

$\mathrm{Glu}^{353}$

$544.9 \rightarrow 824.3$

$[\mathrm{M}+2 \mathrm{H}]^{2+} \rightarrow \mathrm{y}_{6}{ }^{\prime *}$

TYE*TTLEK

30

27

His $^{9}$

$402.0 \rightarrow 586.5$

$[\mathrm{M}+2 \mathrm{H}]^{2+} \rightarrow \mathrm{y}_{6}{ }^{* *} \quad$ TYETTLE*K

30

27

$\mathrm{His}^{9}$

$402.0 \rightarrow 487.0$

$[\mathrm{M}+2 \mathrm{H}]^{2+} \rightarrow \mathrm{y}_{4}{ }^{\prime *} \quad$ SEVAH*R

30

27

His $^{67}$

$374.8 \rightarrow 214.1$

$[\mathrm{M}+2 \mathrm{H}]^{2+} \rightarrow \mathrm{y}_{3}{ }^{\prime *} \quad$ SEVAH ${ }^{*} \mathrm{R}$

30

30

His $^{67}$

$374.8 \rightarrow 543.1$

$[\mathrm{M}+3 \mathrm{H}]^{3+} \rightarrow \mathrm{im}$

SLH*TLFGDK

30

50

His $^{146}$

$616.6 \rightarrow 883.3$

$[\mathrm{M}+3 \mathrm{H}]^{3+} \rightarrow \mathrm{b}_{7} *$

SLH*TLFGDK

30

22

$\mathrm{His}^{338}$

$786.8 \rightarrow 214.1$

$[\mathrm{M}+3 \mathrm{H}]^{3+} \rightarrow \mathrm{b}_{6} *$

H*PYFYAPELLFFAK

30

24

$\mathrm{His}^{338}$

$786.8 \rightarrow 1174.6$

$[\mathrm{M}+2 \mathrm{H}]^{2+} \rightarrow \mathrm{im}$

RH*PDYSVVLLLR

30

68

Lys $^{199}$

$351.5 \rightarrow 388.0$

$[\mathrm{M}+2 \mathrm{H}]^{2+} \rightarrow \mathrm{y}_{10} "$

RH*PDYSVVLLLR

30

50

Lys $^{414}$

$582.2 \rightarrow 900.9$

$[\mathrm{M}+3 \mathrm{H}]^{3+} \rightarrow \mathrm{y}_{3} *$

LK*CASLQK

30

20

Lys $^{414}$

$582.2 \rightarrow 557.3$

$[\mathrm{M}+3 \mathrm{H}]^{3+} \rightarrow \mathrm{y}_{8} "$

K*VPQVSTPTLVEVSR

30

26

Lys $^{525}$

$617.0 \rightarrow 874.9$

$[\mathrm{M}+3 \mathrm{H}]^{3+} \rightarrow \mathrm{b}_{4}$ *

K*VPQVSTPTLVEVSR

38

Lys $^{525}$

$[\mathrm{M}+2 \mathrm{H}]^{2+} \rightarrow \mathrm{b}_{7} *$

K*QTALVELVK

40

$[\mathrm{M}+2 \mathrm{H}]^{2+} \rightarrow \mathrm{b}_{6} *$

K*QTALVELVK

30

40 
Figure 1. Product ion spectra of the ion $[\mathrm{M}+2 \mathrm{H}]^{2+}$ at $\mathrm{m} / \mathrm{z} 786.5$ corresponding to the adducted peptide RH*PDYSVVLLLR (T45-46). The adduct is located on His ${ }^{338}$. The * denotes the site of modification. The immonium ion of THB-His is observed at $\mathrm{m} / \mathrm{z} 214.13$. The analysis was performed with nanoES-QqTOFMS.

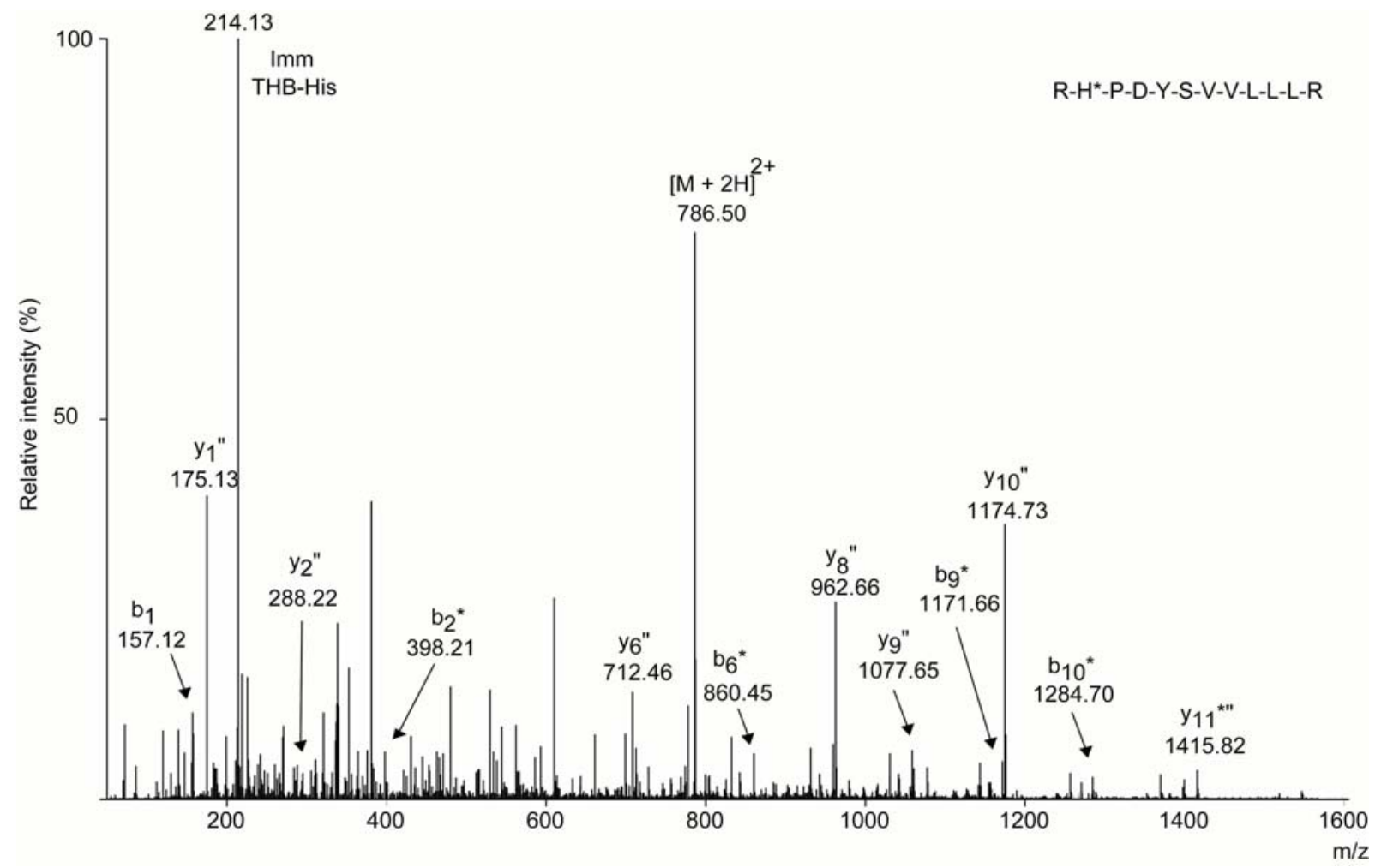


Figure 2. Product ion spectrum of the ion $[\mathrm{M}+2 \mathrm{H}]^{2+}$ at $\mathrm{m} / \mathrm{z} 616.9$ corresponding to the adducted peptide K*QTALVELVK (T69-T70). The THB-adduct is located on Lys ${ }^{525}$. The * denotes the modification sites of the peptides. The analysis was performed with nanoESQqTOFMS.

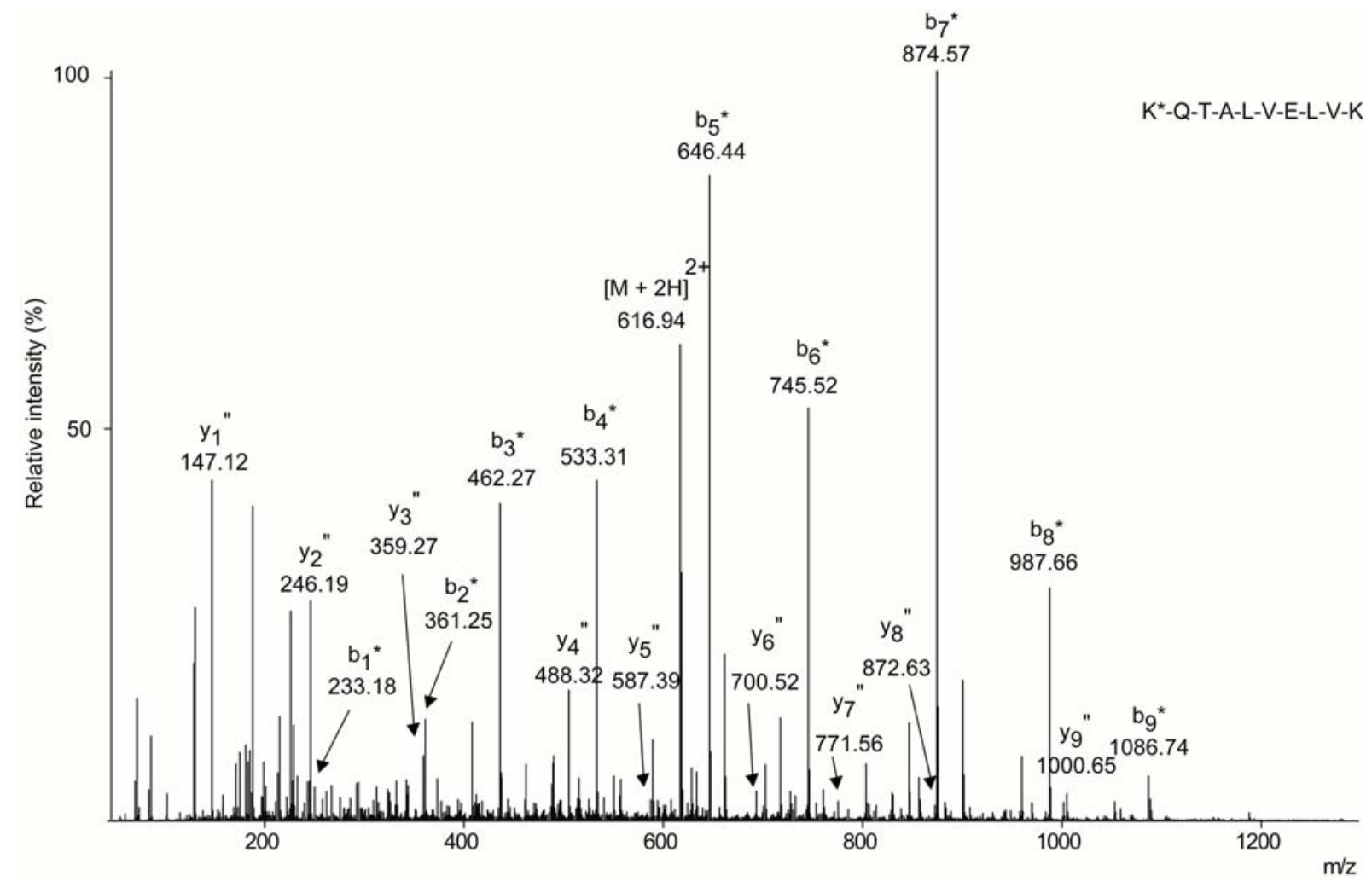




\section{Figure 3.}

LC/MS/MS analyses of the tryptic HSA peptide RH*PDYSVVLLLR with His ${ }^{338}$ adducted. The SRM transition was $\mathrm{m} / \mathrm{z} 786.8 \rightarrow 1174.6$, corresponding to the ions $[\mathrm{M}+2 \mathrm{H}]^{2+} \rightarrow \mathrm{y}_{10}{ }^{\prime \prime}$. (a) of HSA:EBD 1:1 (b) blank HSA. The * denotes the modification sites of the peptides.

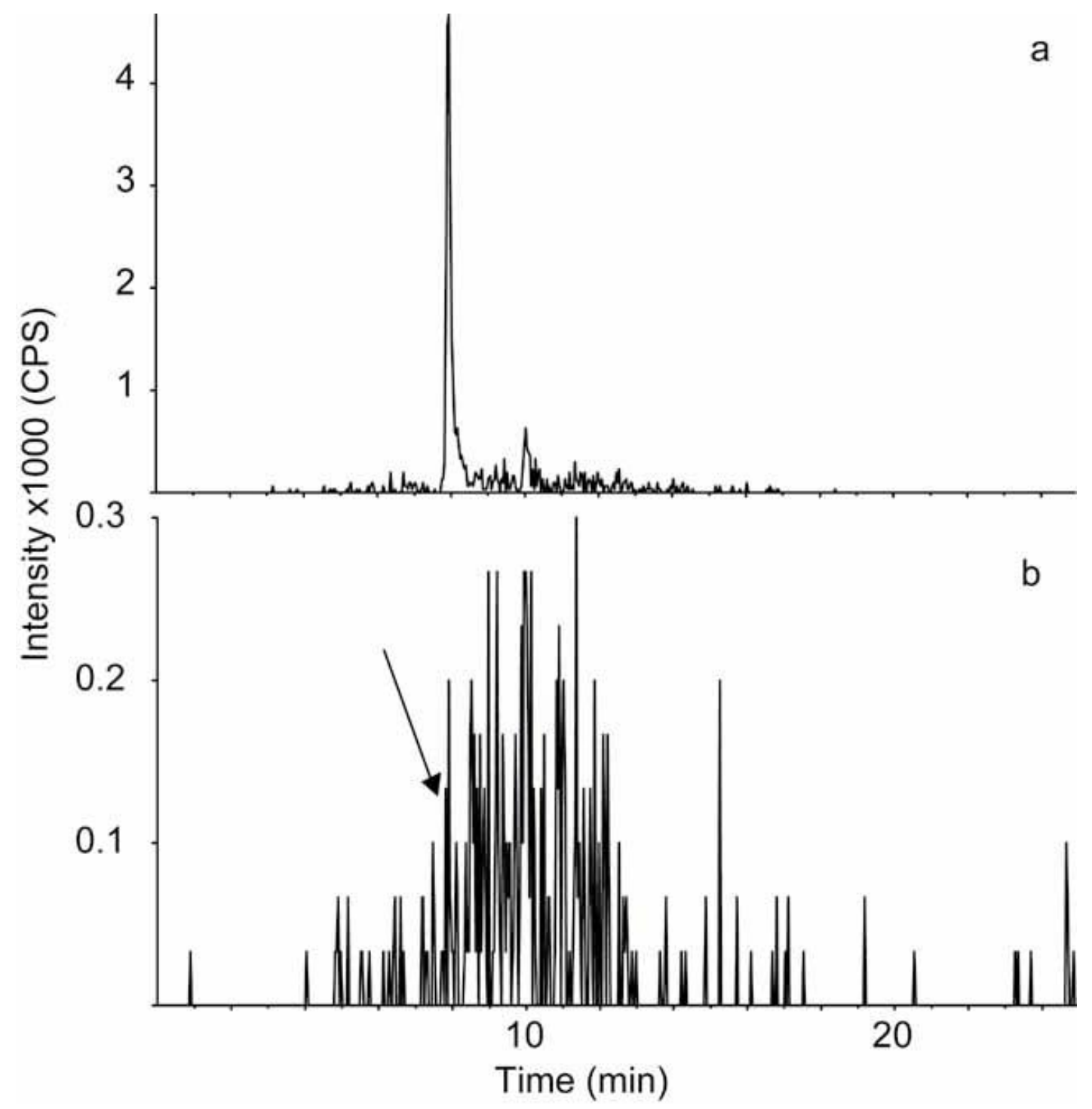




\section{Figure 4.}

LC/MS/MS analyses of the tryptic HSA peptide T69-70 (K*QTALVELVK) with Lys ${ }^{525}$ adducted. The SRM transition was $\mathrm{m} / \mathrm{z} 617.0 \rightarrow 874.9$, corresponding to the ions $[\mathrm{M}+2 \mathrm{H}]^{2+}$ $\rightarrow \mathrm{b}_{7} *$ (a) in the conjugate HSA:EBD 1:1 (b) blank HSA. The * denotes the modification sites of the peptides.

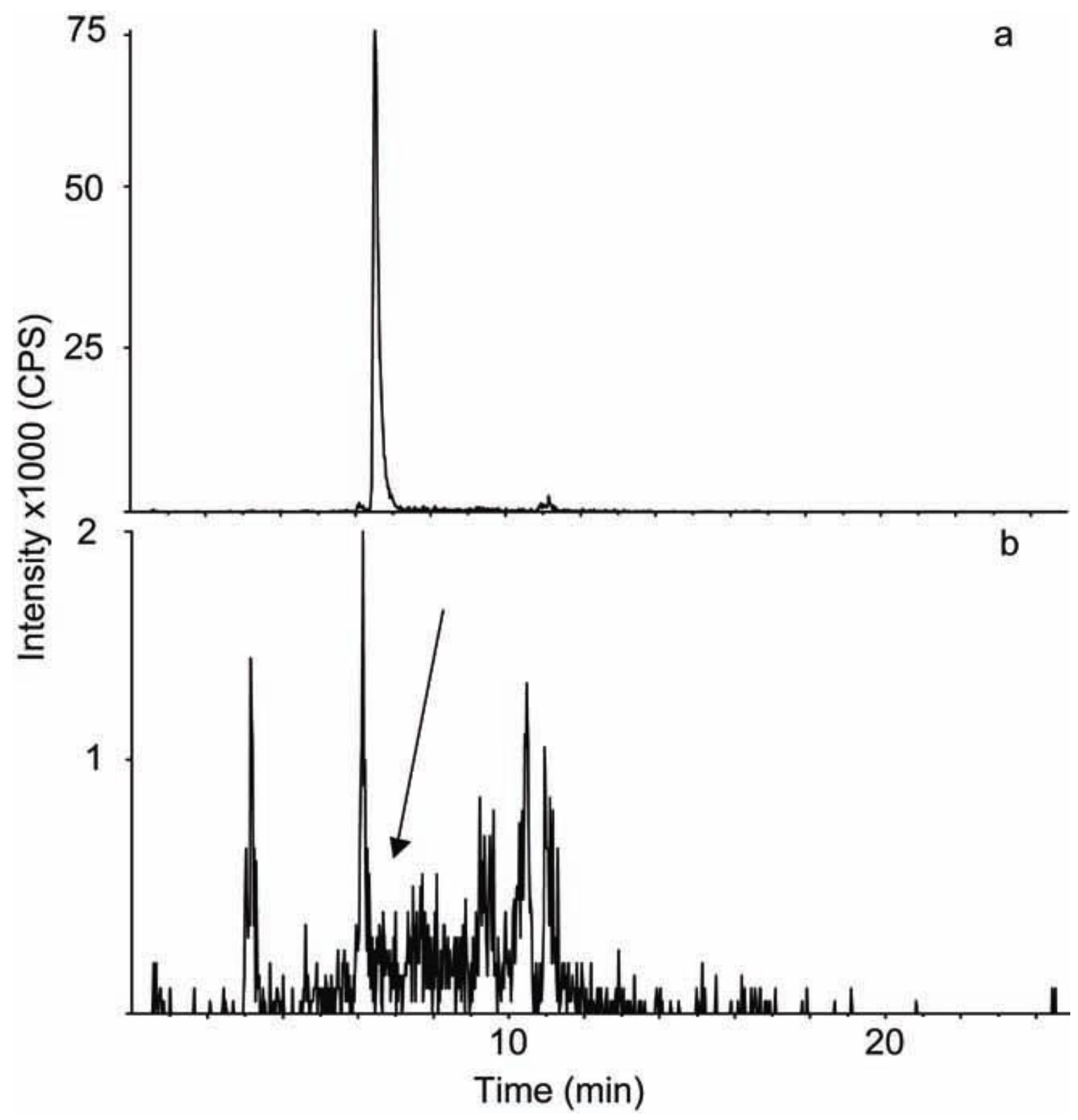




\section{REFERENCES}

IARC Monographs on the Evaluation of Carcinogenic Risks to Humans: Reevaluation of Some Organic Chemicals, Hydrazine and Hydrogen Peroxide. (1999).

Report on carcinogens: carcinogen profiles / U.S. Dept. of Health and Human Services, Public Health Service, National Toxicology Program: Report on carcinogens, tenth edition. Carcinogen profiles 2002. (2002).

Csanady G A, Guengerich F P, Bond J A Carcinogenesis 13 (1992) 1143-1153;

Kreuzer P E, Kessler W, Welter H F, Baur C, Filser J G Arch. Toxicol. 65 (1991) 59-67;

Miraglia N, Basile A, Pieri M, Acampora A, Malorni L, De Giulio B, Sannolo N Rapid Commun. Mass Spectrom. 16 (2002) 840-847;

Basile A, Ferranti P, Pocsfalvi G, Mamone G, Miraglia N, Caira S, Ambrosi L, Soleo L, Sannolo N, Malorni A Rapid Commun. Mass Spectrom. 15 (2001) 527540; DOI: 10.1002/rcm.263.

Badghisi H, Liebler D C Chem. Res. Toxicol. 15 (2002) 799-805; DOI: 10.1021/tx015589+.

Moll T S, Harms A C, Elfarra A A Chem.-Biol. Interact. 135-136 (2001) 667674; DOI:10.1016/S0009-2797(01)00206-X.

Moll T S, Harms A C, Elfarra A A Chem. Res. Toxicol. 13 (2000) 1103-1113; DOI: $10.1021 /$ tx000151f.

Roepstorff P, Fohlman J Biomed. Mass Spectrom. 11 (1984) 601-601;

Rosqvist S, Johannesson G, Lindh C H, Jonsson B A G J. Environ. Monit. 2 (2000) 155-160;

Kristiansson M H, Lindh C H, Jonsson B A G Biomarkers 8 (2003) 343-359; DOI: $10.1080 / 13547500310001607836$.

Brunmark P, Harriman S, Skipper P L, Wishnok J S, Amin S, Tannenbaum S R Chem. Res. Toxicol. 10 (1997) 880-886; DOI: 10.1021/tx9700782.

Day B W, Skipper P L, Zaia J, Singh K, Tannenbaum S R Chem. Res. Toxicol. 7 (1994) 829-835;

Alvarez-Sanchez R, Divkovic M, Basketter D, Pease C, Panico M, Dell A, Morris H, Lepoittevin J P Chem. Res. Toxicol. 17 (2004) 1280-1288; DOI 10.1021/tx049935+.

Noort D, Hulst A G, Fidder A, van Gurp R A, de Jong L P A, Benschop H P Chem. Res. Toxicol. 13 (2000) 719-726; DOI: 10.1021/tx000022z.

Ding A, Ojingwa J C, McDonagh A F, Burlingame A L, Benet L Z Proc. Natl. Acad. Sci. U. S. A. 90 (1993) 3797-3801;

Iberg N, Fluckiger R J. Biol. Chem. 261 (1986) 3542-3545;

Ding A, Ziaamirhosseini P, McDonagh A F, Burlingame A L, Benet L Z Drug Metab. Dispos. 23 (1995) 369-376;

Ziaamirhosseini P, Ding A, Burlingame A L, McDonagh A F, Benet L Z Biochem. J. 311 (1995) 431-435;

Kristiansson M H, Lindh C H, Jonsson B A G Rapid Commun. Mass Spectrom. 18 (2004) 1592-1598; DOI: 10.1002/rcm.1527.

Walker J E FEBS Lett. 66 (1976) 173-175;

Booth E D, Kilgour J D, Watson W Chem.-Biol. Interact. 147 (2004) 213-232;

DOI:10.1016/j.cbi.2004.01.002.

Boogaard P J J. Chromatogr. B 778 (2002) 309-322; DOI:10.1016/S03784347(01)00445-5. 
Kautiainen A, Fred C, Rydberg P, Törnqvist M Rapid Commun. Mass Spectrom. 14 (2000) 1848-1853;

Perez H L, Lahdetie J, Landin H H, Kilpelainen I, Koivisto P, Peltonen K, Osterman-Golkar S Chem.-Biol. Interact. 105 (1997) 181-198;

DOI:10.1016/S0009-2797(97)00049-5.

Rydberg P, Magnusson A L, Zorcec V, Granath F, Tornqvist M Chem.-Biol. Interact. 101 (1996) 193-205; DOI:10.1016/0009-2797(96)03724-6. Moll T S, Elfarra A A Chem. Res. Tox. 12 (1999) 679-689; Kristiansson M H, Jonsson B A G, Lindh C H Chem. Res. Toxicol. 15 (2002) 562-569;

30 Cech N B, Krone J R, Enke C G Rapid Commun. Mass Spectrom. 15 (2001) 1040-1044; DOI: 10.1002/rcm.337.

31 Boysen G, Georgieva N I, Upton P B, Jayaraj K, Li Y T, Walker V E, Swenberg J A Cancer Res. 64 (2004) 8517-8520; 